\section{RMD Open}

Rheumatic \&

Musculoskeletal Diseases

\title{
Determining factors related to impaired spinal and hip mobility in patients with axial spondyloarthritis: longitudinal results from the DESIR cohort
}

To cite: Carvalho PD, RuyssenWitrand A, Fonseca J, et al. Determining factors related to impaired spinal and hip mobility in patients with axial spondyloarthritis: longitudinal results from the DESIR cohort. RMD Open 2020;6:e001356. doi:10.1136/rmdopen-2020001356

- Supplemental material is published online only. To view please visit the journal online (http://dx.doi.org/10.1136/rmdo pen-2020-001356)

Received 8 June 2020 Revised 10 September 2020 Accepted 15 September 2020

Check for updates

(c) Author(s) (or their employer(s)) 2020. Re-use permitted under CC BY-NC. No commercial re-use. See rights and permissions. Published by BMJ.

For numbered affiliations see end of article.

Correspondence to

Pedro M Machado;

p.machado@ucl.ac.uk

\section{ABSTRACT}

Objective To investigate the determinants of impaired spinal and hip mobility in patients with early axial spondyloarthritis (axSpA).

Methods Five-year longitudinal data from the DEvenir des Spondyloarthrites Indifférenciées Récentes (DESIR) cohort were analysed. Associations were investigated using generalised estimating equations, using Bath Ankylosing Spondylitis Metrology Index (BASMI) linear or each of the five components of BASMI as dependent variables, and clinical and demographic variables as independent variables in univariable models. Multivariable analyses were performed, adjusting for potential confounders.

Results Data from 644 patients and 5152 visits were analysed. Higher BASMI values were independently and positively associated with Ankylosing Spondylitis Disease Activity Score $C$ reactive protein (ASDAS-CRP) (adjusted $B(\operatorname{adjB})=0.21 ; 95 \% \mathrm{Cl}=0.15$ to 0.28$)$, MRI spinal inflammation score (adjB=0.11; $95 \% \mathrm{Cl}=0.04$ to 0.19 ), enthesitis score $(\operatorname{adj} \mathrm{B}=0.02 ; 95 \% \mathrm{Cl}=0.01$ to 0.04$)$ and age (adjB $=0.02 ; 95 \% \mathrm{Cl}=0.01$ to 0.03 ). All BASMl components were independently associated with ASDAS-CRP and MRI spinal inflammation, except for maximal intermalleolar distance (reflecting hip mobility), which was not associated with MRI spinal inflammation.

Conclusion In early axSpA, spinal mobility impairment is independently determined by clinical disease activity, MRI spinal inflammation, enthesitis and age. The influence of spinal inflammation prevails in early axSpA, as opposed to spinal structural damage, which may become more relevant in later disease stages.

\section{INTRODUCTION}

Classical hallmarks of axial spondyloarthritis (axSpA) are chronic back pain, stiffness and impairment of spinal and hip mobility. The Assessment in SpondyloArthritis international Society (ASAS) recommends spinal mobility as a core domain in both clinical practice and trials, ${ }^{1}$ and the European Medicines Agency states that "spinal mobility is of

\section{Key messages}

What is already known about this subject?

- Spinal mobility is a core domain of axial spondyloarthritis (axSpA) assessment.

- Spinal mobility is a complex outcome, which is highly influenced by clinical and individual factors.

- In radiographic axSpA, spinal mobility impairment is independently determined by irreversible spinal structural damage and reversible spinal inflammation.

What does this study add?

- In early axSpA, spinal mobility impairment is independently determined by clinical disease activity, MRI spinal inflammation, enthesitis and age.

- In the early stages of axSpA, disease activity and spinal inflammation seem to play a more relevant role than structural damage on mobility.

- Clinical disease activity, enthesitis and spinal inflammation are critical factors influencing mobility -they complement each other and they are all amenable to treatment.

How might this impact on clinical practice?

- The multifactorial aspects of spinal and hip mobility need to be taken into account when interpreting absolute and change mobility scores.

- Early treatment of clinical symptoms, enthesitis and reversible spinal inflammation may be of great importance in recovering mobility and achieving better patient outcomes.

- This study supports the widespread use of ASDAS, as this index showed a good association with all BASMI components, therefore further validating this measure.

great importance in axSpA and constitutes the most organ specific domain', spinal mobility 'is considered an important measure to assess efficacy' and 'imaging methods should be supported by a demonstration of an effect on the clinical consequences of the slowing or 
prevention of the structural damage (i.e. an effect on spinal mobility)'. ${ }^{2}$ It is therefore of utmost importance to understand the factors that influence spinal (and hip) mobility in axSpA.

Spinal mobility has been more extensively studied in patients with axSpA with long-standing disease compared with patients at earlier disease stages. Nevertheless, recent evidence points to the presence of significant mobility impairment even in early disease. ${ }^{3}$ Furthermore, the axSpA disease spectrum should be understood as a whole, and the study of the determinants of mobility in earlier disease stages will promote a better knowledge of the disease itself, as it is likely that the relative contribution of factors associated with spinal mobility in axSpA will change over time.

It has been shown that spinal mobility impairment is independently determined both by irreversible spinal damage and by reversible spinal inflammation. However, as mentioned earlier, these relationships have been investigated mainly in patients with longstanding disease (ankylosing spondylitis (AS)) and at the cross-sectional level only. Moreover, only the composite score Bath Ankylosing Spondylitis Metrology Index (BASMI) has been evaluated rather than individual components of BASMI (tragus-to-wall distance, cervical rotation, anterior lumbar flexion, lateral spinal flexion and maximal intermalleolar distance)..$^{45}$

Our aim was to investigate the determinants of impaired spinal and hip mobility in patients with early axSpA.

\section{METHODS}

We analysed longitudinal data from the DEvenir des Spondyloarthrites Indifférenciées Récentes (DESIR) cohort, collected during the first 5 years of follow-up. This is a prospective observational cohort of patients aged 18-50 years with recent onset ( $>3$ months, $<3$ years) inflammatory back pain (Calin or the Berlin criteria), suggestive of axSpA (level of confidence $\geq 5$ / $10)$, as previously described. ${ }^{6}$ We selected patients with a definite diagnosis of axSpA according to the treating rheumatologist, at the end of follow-up (month 60).

Mobility was assessed using the linear definition of BASMI (range 0-10, with higher scores reflecting worse mobility), and using the individual components of BASMI: tragus-to-wall distance $(\mathrm{cm})$, cervical rotation (degrees), anterior lumbar flexion (modified Schöber; $\mathrm{cm}$ ), lateral spinal flexion $(\mathrm{cm})$ and maximal intermalleolar distance $(\mathrm{cm}) \cdot{ }^{7-9}$ Disease activity was measured using the AS Disease Activity Score C reactive protein (ASDAS-CRP), a composite index that incorporates the assessment of four different domains (back pain, duration of morning stiffness, global assessment of disease activity, peripheral pain/swelling), scored on a $0-10$ numeric rating scale by patients, plus an inflammatory marker (CRP) ${ }^{10-12}$ The concise Mander Enthesitis Score
(cMES) with gradation was used to evaluate enthesitis involvement. This score considers 13 entheseal sites corresponding to mainly axial locations: left and right first costochondral joint, left and right seventh costochondral joint, left and right posterior superior iliac spine, left and right anterior superior iliac spine, left and right iliac crest, left and right proximal insertion of Achilles tendon and fifth lumbar spinous process. Each one of the sites is graded from 0 to 3 ( $0=$ no pain; $1=$ mild tenderness; $2=$ moderate tenderness; $3=$ wince or withdraw), the total range being from 0 to $39 .{ }^{13}$ The following entheseal sites $(\mathrm{N}=7)$ were arbitrarily defined as 'pure axial sites' for the purpose of sensitivity analyses: left and right first costochondral joint, left and right seventh costochondral joint, left and right posterior superior iliac spine and fifth lumbar spinous process. Spinal MRI inflammation and sacroiliac joint (SIJ) MRI inflammation were assessed using the Berlin scoring system and the Spondyloarthritis Research Consortium of Canada (SPARCC) scoring system, respectively; spinal and hip radiographic structural damage were assessed using the modified Stoke AS Spinal Score (mSASSS) ${ }^{9}$ and the Bath Ankylosing Spondylitis Radiology Index for the hips (BASRIhips; the mean score of both hips was used in the present study), ${ }^{14}$ respectively. Treatment with nonsteroidal antiinflammatory drugs (NSAID), conventional diseasemodifying antirheumatic drugs (cDMARD) and antitumour necrosis factor (anti-TNF) drugs were assessed according to their intake in the 6 months before each visit (yes or no).

Associations were tested using generalised estimating equations, a multilevel approach that uses all available data during follow-up, while taking into account missing values, and adjusting for within-patient correlation. ${ }^{15}$ Only observed data were used, imputation was not performed. The BASMI total score or the individual measurements of the BASMI components were used as dependent variables, and clinical and demographic variables (age; gender; level of education; body mass index (BMI); human leucocyte antigen B27 (HLA-B27) status; symptom duration; employment status; smoking status; presence of current peripheral arthritis; enthesitis score; ASDAS-CRP; mSASSS; BASRI-hips; total Berlin score of the spine; total SPARCC score of the SIJs; and NSAID, cDMARD and anti-TNF intake in the last 6 months) were used as independent variables in univariable models. The BASRI-hips was only used to test associations with the BASMI total score and with maximal intermalleolar distance. As physical function and quality of life are health domains considered to be hierarchically superior to spinal mobility, they were not included in the analyses. ${ }^{4}$ Multivariable models were then performed, adjusting for potential confounding factors. Variables with a $\mathrm{p}$ value $<0.05$ were retested in those multivariable models. Six models were built, one regarding the BASMI and five regarding the individual components of BASMI. A sensitivity analysis using purely axial entheseal sites was performed. 


\section{RESULTS}

From the 708 patients enrolled in the DESIR cohort, we excluded 64 from our analysis as they did not have a definite clinical diagnosis of axSpA at month 60. Data from 644 patients and 5152 visits collected during 60 months were analysed (online supplemental table 1). This was a young and early disease cohort (mean age 33.6 $( \pm 8.6)$ years; mean symptom duration $1.5( \pm 0.9)$ years $)$ comprising 303 male patients $(47.0 \%)$ with a very low level of structural damage at baseline (mean mSASSS $0.4( \pm 1.6)$ units $)$. Mean BASMI at baseline was 2.4 $( \pm 1.0)$, reflecting an overall low level of mobility impairment. At month 60, only $113(17.5 \%)$ of the patients had a diagnosis of AS (ie, radiographic axSpA).

In the univariable analysis, male gender, education (university or equivalent), higher BMI and HLA-B27 positivity were associated with better mobility as assessed by BASMI. Conversely, older age, higher ASDAS-CRP, enthesitis score, mSASSS, spinal MRI Berlin score, BASRI-hips score and NSAID intake in the last 6 months were associated with poorer mobility (table 1). Regarding the individual components of BASMI, significant associations with clinical and imaging variables are also presented in table 1. Online supplemental table 2 presents the results of all univariable analysis, either significant or non-significant.

In the multivariable analyses (table 2), we found an independent association between higher BASMI values (worse mobility) and age (adjusted B (adjB) $=0.02 ; 95 \%$ $\mathrm{CI}=0.01$ to 0.03$)$, ASDAS-CRP $(\operatorname{adjB}=0.21 ; 95 \% \mathrm{CI}=0.15$ to $0.28)$, enthesitis score $(\operatorname{adj} \mathrm{B}=0.02 ; 95 \% \mathrm{CI}=0.01$ to 0.04 ), BASRI-hips (adjB $=0.65 ; 95 \% \mathrm{CI}=0.31$ to 1.00$)$ and MRI spinal inflammation score $(\operatorname{adjB}=0.11 ; 95 \% \mathrm{CI}=0.04$ to $0.19)$. Better mobility measured by BASMI was associated with BMI (adjB $=-0.04 ; 95 \% \mathrm{CI}=-0.06$ to -0.01$)$ and HLA$\mathrm{B} 27$ positivity ( $\operatorname{adjB}=-0.24 ; 95 \% \mathrm{CI}=-0.41$ to -0.08 ).

Disease activity measured by ASDAS-CRP was independently associated with all individual BASMI components, and this index was the only variable that kept its significance along the multivariable models for each one of the BASMI components. Apart from maximal intermalleolar distance (a measure of hip mobility), all other individual mobility measures (measures of spinal mobility) were associated with MRI spinal inflammation. mSASSS was only associated with lateral spinal flexion and was a (nonsignificant) contributory factor to tragus-to-wall distance and cervical rotation. Other variables presenting consistent and significant associations across spinal and hip mobility measures were age and enthesitis score (both influencing 4/6 mobility measures), followed by gender, BMI, HLA-B27 positivity and symptom duration (all influencing $3 / 6$ mobility measures) (figure 1 ).

A sensitivity analysis performed using the enthesitis score limited to purely axial entheseal sites yielded similar results (online supplemental table 3) for BASMI, cervical rotation and maximal intermalleolar distance. However, the association with lateral spinal flexion was lost (and similarly to the main model; it was associated neither with tragus-to-wall distance nor with anterior lumbar flexion).
In addition, the best-fit model for maximal intermalleolar distance now included BASRI-hips as a variable with a significant association with this mobility measure.

\section{DISCUSSION}

This study provides evidence of a consistent and independent association between disease activity measured by ASDAS-CRP and multiple spinal and hip mobility measures in an early axSpA cohort with low levels of spinal structural damage. Moreover, inflammation measured by MRI was a key determinant of spinal mobility. Maximal intermalleolar distance (a measure of hip mobility) was the only measure not associated with MRI spinal inflammation. More severe enthesitis and older age also showed consistent and independent associations with worse mobility.

In late-stage disease, the importance of spinal inflammation along with structural damage for spinal mobility had already been established, at the cross-sectional level. ${ }^{4} 5{ }^{5} 16 \quad 17$ However, in early disease stages, given the low levels of structural damage, spinal structural damage may not be the main factor determining mobility impairment, and our results point to a more important role of clinical disease activity, enthesitis and MRI inflammation in determining spinal and hip mobility impairment. The importance of spinal inflammation in early disease had already been suggested in patients with AS who had less than 3 years of disease, ${ }^{5}$ and recently in patients with early axSpA with a mean duration of back pain inferior to 1 year. ${ }^{3}$

Mobility had already been described as independently associated with ASDAS-CRP and age in early ${ }^{3}$ and late disease. ${ }^{18}$ Even in healthy population, mobility tends to decrease with age. This observation led to the creation of reference intervals for mobility measures, which take into account the individual's age and height. ${ }^{19}$ To our knowledge, this is the first study reporting an association between lower enthesitis scores and better mobility. As cMES evaluates several entheseal sites in relation with spinal and hip movement, the inflammatory process in the entheses might be leading to pain and local damage of the entheses and associated tendons, which would subsequently contribute to the impairment of spinal and hip mobility. The contribution of peripheral arthritis to tragus-to-wall distance and cervical rotation may suggest that the overall disease inflammatory state plays a role on spinal mobility through the inflammation of several other structures not specifically assessed in this study.

All clinical and imaging variables had consistent associations with each one of the five individual BASMI components, apart for less consistent associations seen with gender, symptom duration and BMI. In axSpA, women tend to present higher disease activity levels and higher involvement of peripheral joints, ${ }^{20}{ }^{21}$ while spinal mobility tends to be better in women compared to men. ${ }^{21}{ }^{22} \mathrm{In}$ our study, being a men was independently associated with better lateral spinal flexion and maximal intermalleolar 
Table 1 Univariable GEE results (B; $95 \% \mathrm{Cl}$ ) presenting significant associations ${ }^{*}$ between BASMI linear (or its components) and clinical and demographic variables

\section{Mobility measures where higher}

values represent worse mobility

Mobility measures where higher values represent better mobility

\begin{tabular}{|c|c|c|c|c|c|c|}
\hline & & & & & \\
\hline & BASMI linear & $\begin{array}{l}\text { Tragus-to-wall } \\
\text { distance }\end{array}$ & $\begin{array}{l}\text { Lateral spinal } \\
\text { flexion }\end{array}$ & $\begin{array}{l}\text { Cervical } \\
\text { rotation }\end{array}$ & $\begin{array}{l}\text { Anterior } \\
\text { lumbar } \\
\text { flexion }\end{array}$ & $\begin{array}{l}\text { Maximal } \\
\text { intermalleolar } \\
\text { distance }\end{array}$ \\
\hline Age & $\begin{array}{l}0.02 \\
\text { (0.01 to } 0.03)\end{array}$ & & $\begin{array}{l}-0.16 \\
(-0.20 \text { to }-0.13)\end{array}$ & $\begin{array}{l}-0.31 \\
(-0.40 \text { to }-0.22)\end{array}$ & & $\begin{array}{l}-0.19 \\
(-0.33 \text { to }-0.06)\end{array}$ \\
\hline Male gender & $\begin{array}{l}-0.28 \\
(-0.41 \text { to }-0.16)\end{array}$ & $\begin{array}{l}0.84 \\
(0.61 \text { to } 1.06)\end{array}$ & $\begin{array}{l}1.99 \\
\text { (1.39 to } 2.59)\end{array}$ & $\begin{array}{l}1.81 \\
(0.12 \text { to } 3.50)\end{array}$ & & $\begin{array}{l}7.44 \\
\text { (4.93 to } 9.94)\end{array}$ \\
\hline Education† & $\begin{array}{l}-0.39 \\
(-0.52 \text { to }-0.26)\end{array}$ & $\begin{array}{l}-0.34 \\
(-0.59 \text { to }-0.09)\end{array}$ & $\begin{array}{l}1.52 \\
(0.90 \text { to } 2.14)\end{array}$ & $\begin{array}{l}4.84 \\
\text { (3.08 to } 6.59)\end{array}$ & & $\begin{array}{l}8.24 \\
\text { (5.59 to } 10.90)\end{array}$ \\
\hline BMI & $\begin{array}{l}-0.01 \\
(-0.03 \text { to } 0.00)\end{array}$ & $\begin{array}{l}0.06 \\
(0.03 \text { to } 0.08)\end{array}$ & & & $\begin{array}{l}0.05 \\
(0.03 \text { to } 0.07)\end{array}$ & \\
\hline HLA-B27 positive & $\begin{array}{l}-0.27 \\
(-0.40 \text { to }-0.14)\end{array}$ & & & $\begin{array}{l}3.41 \\
\text { (1.68 to } 5.13)\end{array}$ & & $\begin{array}{l}6.51 \\
\text { (3.86 to } 9.17)\end{array}$ \\
\hline Symptom duration & & & $\begin{array}{l}-0.24 \\
(-0.31 \text { to }-0.18)\end{array}$ & & $\begin{array}{l}0.03 \\
(0.01 \text { to } 0.05)\end{array}$ & $\begin{array}{l}0.38 \\
(0.13 \text { to } 0.64)\end{array}$ \\
\hline $\begin{array}{l}\text { Currently } \\
\text { employed }\end{array}$ & & & & & $\begin{array}{l}0.18 \\
(0.05 \text { to } 0.32)\end{array}$ & \\
\hline Current arthritis & & & & $\begin{array}{l}-2.42 \\
(-4.24 \text { to }-0.61)\end{array}$ & $\begin{array}{l}-0.16 \\
(-0.31 \text { to } 0.00)\end{array}$ & \\
\hline ASDAS-CRP & $\begin{array}{l}0.16 \\
\text { (0.13 to } 0.19)\end{array}$ & $\begin{array}{l}0.12 \\
(0.05 \text { to } 0.18)\end{array}$ & $\begin{array}{l}-0.54 \\
(-0.67 \text { to }-0.40)\end{array}$ & $\begin{array}{l}-1.89 \\
(-2.41 \text { to }-1.37)\end{array}$ & $\begin{array}{l}-0.12 \\
(-0.16 \text { to }-0.08)\end{array}$ & $\begin{array}{l}-2.56 \\
(-3.13 \text { to }-1.98)\end{array}$ \\
\hline Enthesitis score & $\begin{array}{l}0.02 \\
\text { (0.01 to } 0.03 \text { ) }\end{array}$ & & $\begin{array}{l}-0.09 \\
(-0.12 \text { to }-0.06)\end{array}$ & $\begin{array}{l}-0.37 \\
(-0.46 \text { to }-0.27)\end{array}$ & & $\begin{array}{l}-0.41 \\
(-0.56 \text { to }-0.26)\end{array}$ \\
\hline mSASSS & $\begin{array}{l}0.07 \\
(0.03 \text { to } 0.10)\end{array}$ & $\begin{array}{l}0.17 \\
(0.06 \text { to } 0.28)\end{array}$ & $\begin{array}{l}-0.28 \\
(-0.39 \text { to }-0.17)\end{array}$ & $\begin{array}{l}-0.98 \\
(-1.51 \text { to }-0.46)\end{array}$ & & \\
\hline BASRI-hips & $\begin{array}{l}0.52 \\
\text { (0.23 to } 0.82)\end{array}$ & $\ddagger$ & $\ddagger$ & $\ddagger$ & $\ddagger$ & \\
\hline $\begin{array}{l}\text { MRI inflammation } \\
\text { score (spine) }\end{array}$ & $\begin{array}{l}0.15 \\
(0.08 \text { to } 0.23)\end{array}$ & $\begin{array}{l}0.36 \\
(0.13 \text { to } 0.58)\end{array}$ & $\begin{array}{l}-0.63 \\
(-0.91 \text { to }-0.34)\end{array}$ & $\begin{array}{l}-1.43 \\
(-2.18 \text { to }-0.64)\end{array}$ & $\begin{array}{l}-0.12 \\
(-0.19 \text { to }-0.05)\end{array}$ & \\
\hline $\begin{array}{l}\text { MRI inflammation } \\
\text { score (SIJ) }\end{array}$ & & & $\begin{array}{l}0.07 \\
(0.02 \text { to } 0.12)\end{array}$ & & & \\
\hline $\begin{array}{l}\text { NSAID intake in } \\
\text { the last } 6 \text { months }\end{array}$ & $\begin{array}{l}0.09 \\
(0.04 \text { to } 0.15)\end{array}$ & & & & & \\
\hline $\begin{array}{l}\text { cDMARD intake in } \\
\text { the last } 6 \text { months }\end{array}$ & & & & & & $\begin{array}{l}-2.04 \\
(-3.67 \text { to }-0.40)\end{array}$ \\
\hline
\end{tabular}

*Only associations with a $\mathrm{p}$ value $<0.05$ are presented (for the full set of univariable results, see online supplemental table 2).

†Education at baseline (university or equivalent).

ҒBASRI-hips was only considered for BASMI linear and for maximal intermalleolar distance.

ASDAS-CRP, Ankylosing Spondylitis Disease Activity Score C reactive protein; BASMI, Bath Ankylosing Spondylitis Metrology Index; BASRIhips, Bath Ankylosing Spondylitis Radiology Index for the hips; BMI, body mass index; cDMARD, conventional disease-modifying antirheumatic drugs; GEE, generalised estimating equations; HLA-B27, human leucocyte antigen B27; mSASSS, Modified Stoke Ankylosing Spondylitis Spinal Score; NSAID, nonsteroidal anti-inflammatory drugs; SIJ, sacroiliac joint.

distance, while tragus-to-wall distance was worse in men compared to women. A recent cross-sectional study aiming to explore the differences regarding mobility in several subgroups of patients with axSpA concluded that gender might not have a major impact in the majority of BASMI components. ${ }^{23}$ These findings are in accordance with the absence of gender-specific reference intervals for the definition of normal spinal mobility measures. ${ }^{19}$ In another study performed with the DESIR cohort, HLAB27 was associated with axial inflammation, less delay in diagnosis and decreased disease activity measured either by ASDAS-CRP or Bath Ankylosing Spondylitis Disease Activity Index. ${ }^{24}$ An earlier diagnosis prompted by HLAB27 and consequently earlier treatment and lower disease activity may be mediating the observed association between HLA-B27 and some of the mobility scores in our study. A higher level of education has been described as being associated with lower disease activity states in $\mathrm{SpA}^{25}$ and also in rheumatoid arthritis, ${ }^{26}$ which again may be mediating the observed association between higher level of education and some of the mobility scores in our study. More educated people may also 
Table 2 Multivariable GEE results (adjB; 95\% Cl) presenting independent associations between BASMl linear (or its components) and clinical and demographic variables

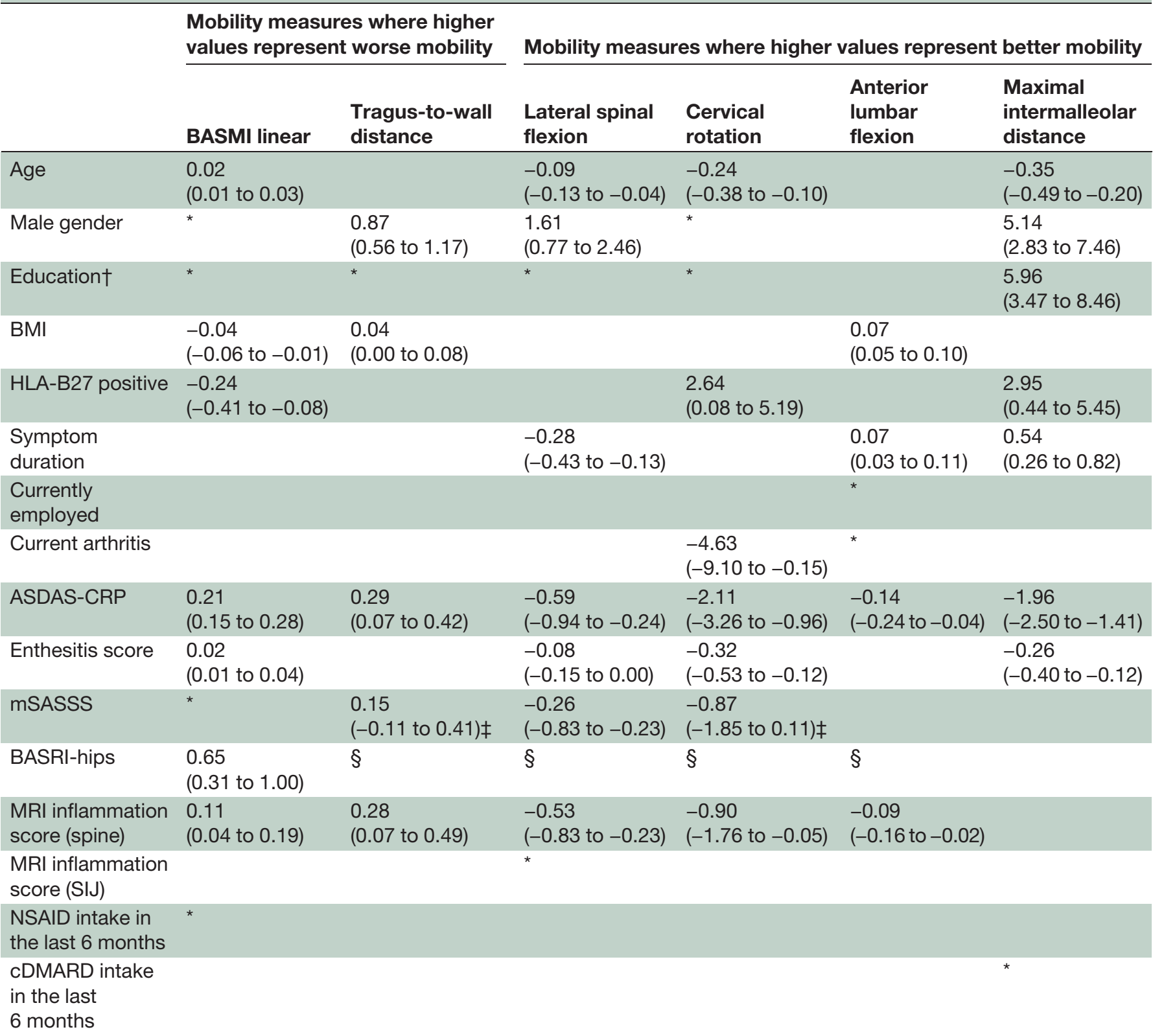

*Statistically significant variables in the univariable analysis but excluded from the best-fit multivariable model;

†Education at baseline (university or equivalent).

¥mSASSS was not significant in the multivariable model but included as it was found to be a contributory variable improving model-fit. $\S B A S R I-h i p s$ was only considered for BASMI linear and for maximal intermalleolar distance.

adjB, adjusted B; ASDAS-CRP, Ankylosing Spondylitis Disease Activity Score C reactive protein; BASMI, Bath Ankylosing Spondylitis Metrology Index; BASRI-hips, Bath Ankylosing Spondylitis Radiology Index for the hips; BMI, body mass index; cDMARD, conventional disease-modifying antirheumatic drugs; GEE, generalised estimating equations; HLA-B27, human leucocyte antigen B27; mSASSS, Modified Stoke Ankylosing Spondylitis Spinal Score; NSAID, nonsteroidal anti-inflammatory drugs; SIJ, sacroiliac joint.

hypothetically have a better understanding of the condition and engage with exercise programmes that may contribute to better mobility. Interestingly, mobility had already been reported as being associated with employment status, ${ }^{27}$ an association that might simply be reflecting the fact that patients with better mobility are more likely to retain their jobs, especially in the context of physically demanding jobs. The absence of a consistent association between mobility and symptom duration may be related to the early disease profile of these patients. However, disease duration may have a more significant impact on mobility in late disease. ${ }^{23}$ Structural damage to the hips was independently associated with worse BASMI but not with maximal intermalleolar distance (non-significant association but numerically in the same direction as with BASMI). However, in the sensitivity analysis with purely axial sites, structural damage to the hips was also independently associated with worse 


\section{Mobility measures with which each variable was independently associated with}

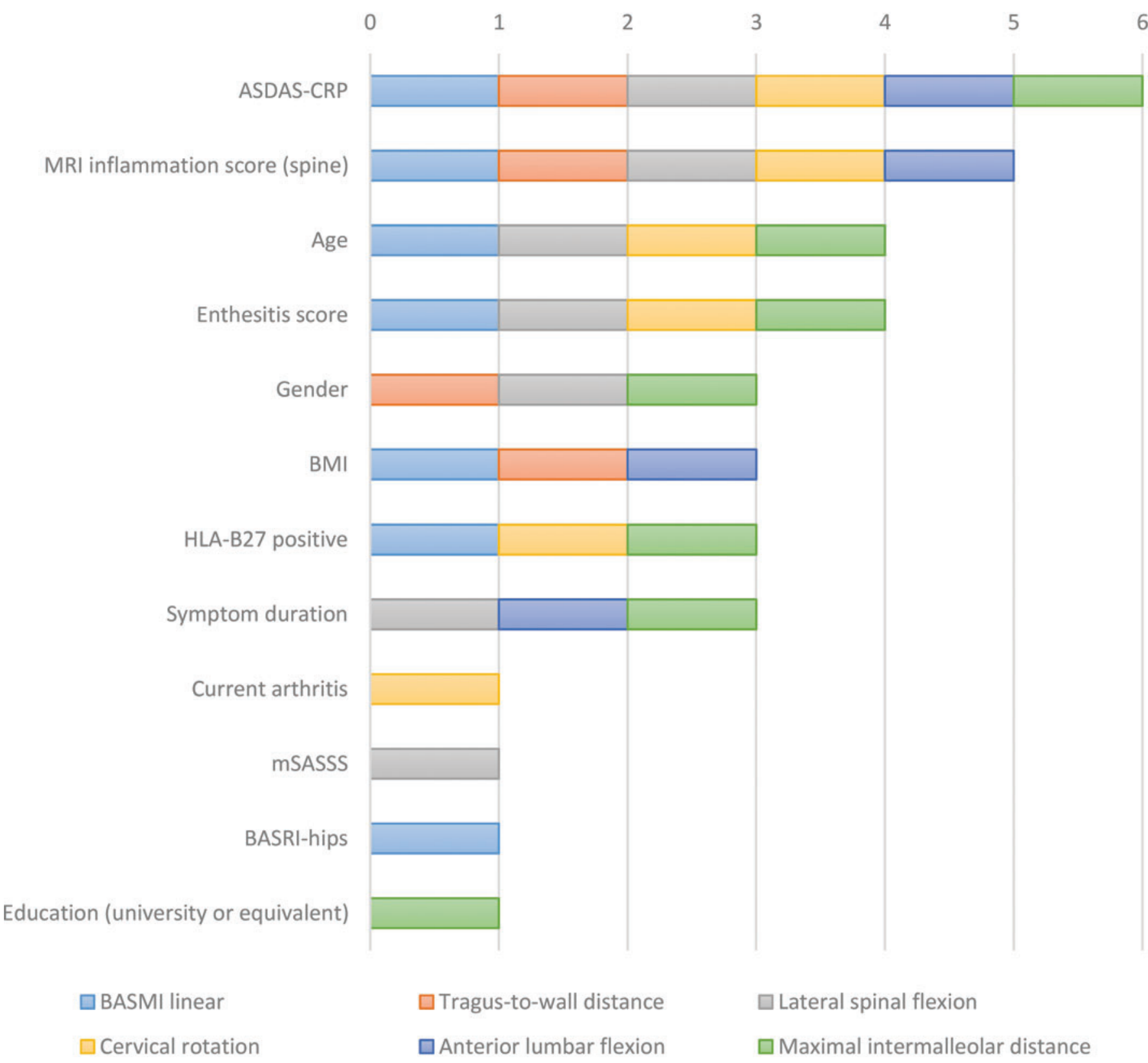

Figure 1 Mobility measures (total BASMI score, tragus-to-wall distance, cervical rotation, anterior lumbar flexion (modified Schöber), lateral spinal flexion and maximal intermalleolar distance) with which each clinical or demographic variable was independently associated with (range 0-6 mobility measures). ASDAS-CRP, Ankylosing Spondylitis Disease Activity Score C reactive protein; BASMI, Bath Ankylosing Spondylitis Metrology Index; BASRI-hips, Bath Ankylosing Spondylitis Radiology Index for the hips; BMI, body mass index; HLA-B27, human leucocyte antigen B27; mSASSS, Modified Stoke Ankylosing Spondylitis Spinal Score.

maximal intermalleolar distance. However, the role of hip damage in the DESIR cohort is difficult to assess and may be residual due to the very low levels of hip damage in this population. Moreover, the sensitivity analysis did not consider the more peripheral entheses-left and right anterior superior iliac spine, left and right iliac crest, and left and right proximal insertion of Achilles tendon - since the iliac spines and crests are pelvic sites, they may theoretically also play a role in hip mobility. While in the primary analysis the effect of pelvic enthesitis might 'surpass' the effect of hip damage, by removing some of the pelvic entheseal sites from the sensitivity analysis might 
have 'uncovered' the effect of hip mobility. Finally, in our study, mSASSS was associated with a measure of lumbarthoracic mobility (lateral spinal flexion) but not with cervical mobility measures. As DESIR is an early disease population, these results may be explained by the reported tendency of axSpA to first involve the lower spine. $^{28}$

Our study has limitations. The Berlin MRI scoring system and the mSASSS do not assess the full spectrum of MRI or radiographic lesions (eg, inflammation/ankylosis of the facets joints are not scored and the thoracic spine is omitted from the mSASSS) and while it can be argued that these scoring systems can be used as a proxy for inflammation/damage in these other structures, this limitation may still have an impact, particularly at the individual level. MRI inflammation of the hip was also not assessed and therefore not controlled for in the analyses. Moreover, despite sites having been instructed with visual aids and text on how to consistently perform the spinal mobility assessments, and the existence of a centralised review process checking for possible inconsistencies (data quality control), the inter-reader and intra-reader reliability of mobility measures was not assessed in this study.

In conclusion, the current study shows that in an early axSpA cohort with minimal spinal radiographic damage, clinical disease activity, measured by ASDAS-CRP, and active spinal inflammation on MRI are major determinants of spinal mobility impairment. Disease activity is also associated with hip mobility impairment. Several other factors influence the degree of both spinal and hip impairment, namely the severity of enthesitis and older age, and less so spinal radiographic damage which may have a more prominent role in later disease stages.

\author{
Author affiliations \\ ${ }^{1}$ Department of Rheumatology, Centro Hospitalar Universitário do Algarve, Faro, \\ Portugal \\ ${ }^{2}$ Rheumatology Research Unit, Instituto de Medicina Molecular, Universidade de \\ Lisboa, Lisbon, Portugal \\ ${ }^{3}$ Algarve Biomedical Center, Faro, Portugal \\ ${ }^{4}$ Centre Hospitalier Universitaire de Toulouse, Toulouse, France \\ ${ }^{5}$ Department of Rheumatology, Santa Maria Hospital - CHLN, Lisbon, Portugal \\ ${ }^{6}$ Universidade do Algarve, Faro, Portugal \\ ${ }^{7}$ Centre for Rheumatology and Department of Neuromuscular Diseases, University \\ College London, London, UK \\ ${ }^{8}$ Department of Rheumatology, University College London Hospitals NHS Foundation \\ Trust, London, UK \\ ${ }^{9}$ Department of Rheumatology, Northwick Park Hospital, London North West \\ University Healthcare NHS Trust, London, UK
}

\section{Twitter Pedro M Machado @pedrommcmachado.}

Acknowledgements The DESIR study is conducted with Assistance Publique Hopitaux de Paris as the sponsor. The DESIR study is also under the umbrella of the French Society of Rheumatology, which financially supports the cohort. An unrestricted grant from Pfizer has been allocated for the first 10 years. The DESIR cohort is conducted under the control of Assistance Publique Hopitaux de Paris via the Clinical Research Unit Paris Centre and under the umbrella of the French Society of Rheumatology and Institut national de la santé et de la recherche médicale (Inserm). Database management is performed within the Department of Epidemiology and Biostatistics (Dr Pascale FABBRO-PERAY, D.I. M., and Nımes, France). We also wish to thank the different regional participating centres: Pr Maxime Dougados, Dr Anna MOLTO (Paris-Cochin), Pr Philippe Dieudé (Paris-Bichat), Pr Laure GOSSEC (Paris-La Pitie-Salpétriere),
Pr Francis Berenbaum (Paris-Saint-Antoine), Pr Pascal Claudepierre (Creteil), Pr Maxime Breban (Boulogne-Billancourt), Dr Bernadette Saint-Marcoux (Aulnay-sous-Bois), Pr Philippe Goupille (Tours), Pr Jean Francis Maillefert (Dijon), Dr Emmanuelle Dernis (Le Mans), Pr Daniel Wendling (Besancon), Pr Bernard Combe (Montpellier), Pr Liana Euller-Ziegler (Nice), Pr Pascal Richette (Paris Lariboisière), Pr Pierre Lafforgue (Marseille), Pr Patrice Fardellone, Dr Patrick Boumier (Amiens), Pr Martin Soubrier (Clermont-Ferrand), Dr Nadia Mehsen (Bordeaux), Pr Damien Loeuille (Nancy), Pr Rene-Marc Flipo (Lille), Pr Alain Saraux (Brest), Pr Stephan PAVY (LeKremlin-Bicetre), Pr Adeline RUYSSEN-WITRAND (Toulouse), Pr Olivier Vittecoq (Rouen). We wish to thank the research nurses, the staff members of the Clinical Research Unit of Paris Centre, the staff members of the Biological Resource Center of Bichat Hospital, the staff members of the Department of Statistics of Nimes and all the investigators, and in particular Jerome Allain, Thierry LEQUERRE, Beatrice Banneville, Julien CHAMPEY, Christine Piroth, Anne Tournadre, Sophie TRIJAU, Salah Ferkal, Clement Prati, Marie-Agnes Timsit, Eric Toussirot for active patient recruitment and monitoring.

Contributors PDC and PMM designed the study. PDC cleaned the database and performed the statistical analyses under the supervision of AM and PMM. PDC and PMM drafted the first version of the manuscript. All those listed as authors read, commented on and approved the final manuscript.

Funding The authors have not declared a specific grant for this research from any funding agency in the public, commercial or not-for-profit sectors. Pedro M Machado is supported by the National Institute for Health Research (NIHR) University College London Hospitals (UCLH) Biomedical Research Centre (BRC). The views expressed are those of the authors and not necessarily those of the (UK) National Health Service (NHS), the NIHR, or the (UK) Department of Health.

Competing interests PMM has received consulting/speaker's fees from Abbvie, BMS, Celgene, Janssen, MSD, Novartis, Pfizer, Roche and UCB; JEF has received grants and/or consulting/speaker's fees from Abbvie, Ache, Bial, Biogen, BMS, Janssen, Lilly, MSD, Novartis, Pfizer, Roche, Sanofi and UCB; The other authors have declared no conflicts of interest.

Patient consent for publication Not required.

Provenance and peer review Not commissioned; externally peer reviewed.

Data availability statement The data sets generated and/or analysed during the current study are not publicly available due to consent restrictions. Programming codes used for statistical analysis during the current study are available from the corresponding author upon reasonable request.

Supplemental material This content has been supplied by the author(s). It has not been vetted by BMJ Publishing Group Limited (BMJ) and may not have been peer-reviewed. Any opinions or recommendations discussed are solely those of the author(s) and are not endorsed by BMJ. BMJ disclaims all liability and responsibility arising from any reliance placed on the content. Where the content includes any translated material, BMJ does not warrant the accuracy and reliability of the translations (including but not limited to local regulations, clinical guidelines, terminology, drug names and drug dosages), and is not responsible for any error and/or omissions arising from translation and adaptation or otherwise.

Open access This is an open access article distributed in accordance with the Creative Commons Attribution Non Commercial (CC BY-NC 4.0) license, which permits others to distribute, remix, adapt, build upon this work non-commercially, and license their derivative works on different terms, provided the original work is properly cited, appropriate credit is given, any changes made indicated, and the use is non-commercial. See: http://creativecommons.org/licenses/by-nc/4.0/.

\section{ORCID IDs}

Pedro D Carvalho http://orcid.org/0000-0001-8255-4274

Pedro M Machado http://orcid.org/0000-0002-8411-7972

\section{REFERENCES}

1 van der Heijde D, Calin A, Dougados M, et al. Selection of instruments in the core set for DC-ART, SMARD, physical therapy, and clinical record keeping in ankylosing spondylitis. progress report of the ASAS Working Group. Assessments in ankylosing spondylitis. J Rheumatol 1999;26:951-4.

2 Committee for Medicinal Products for Human Use (CHMP) EMA Guideline on the clinical investigation of medicinal products for the treatment of axial spondyloarthritis. 12 October 2017; EMA/CPMP/ EWP/4891/03 Rev.1, Corr 1. 
3 Chui ETF, Tsang HHL, Lee KH, et al. MRI inflammation of facet and costovertebral joints is associated with restricted spinal mobility and worsened functional status. Rheumatology (Oxford, England). 2020 Jan 31.

4 Machado P, Landewé R, Braun J, et al. A stratified model for health outcomes in ankylosing spondylitis. Ann Rheum Dis 2011;70:1758-64.

5 Machado P, Landewe R, Braun J, van der Heijde D. Both structural damage and inflammation of the spine contribute to impairment of spinal mobility in patients with ankylosing spondylitis. Ann Rheum Dis 2010;69:1465-70.

6 Dougados M, Etcheto A, Molto A, et al. Clinical presentation of patients suffering from recent onset chronic inflammatory back pain suggestive of spondyloarthritis: the DESIR cohort. Joint Bone Spine 2015;82:345-51.

7 Jones SD, Porter J, Garrett SL, et al. A new scoring system for the Bath Ankylosing Spondylitis Metrology Index (BASMI). J Rheumatol 1995;22:1609.

8 van der Heijde D, Landewe R, Feldtkeller E. Proposal of a linear definition of the Bath Ankylosing Spondylitis Metrology Index (BASMI) and comparison with the 2-step and 10-step definitions. Ann Rheum Dis 2008;67:489-93.

9 Sieper J, Rudwaleit M, Baraliakos X, et al. The Assessment of SpondyloArthritis international Society (ASAS) handbook: a guide to assess spondyloarthritis. Ann Rheum Dis 2009;68:ii1-44.

10 Lukas C, Landewe R, Sieper J, et al. Development of an ASAS-endorsed disease activity score (ASDAS) in patients with ankylosing spondylitis. Ann Rheum Dis 2009;68:18-24.

11 Machado PM, Landewe RB, van der Heijde DM. Endorsement of definitions of disease activity states and improvement scores for the ankylosing spondylitis disease activity score: results from OMERACT 10. J Rheumatol 2011;38:1502-6.

12 Machado PM, Landewe R, Heijde DV. Ankylosing Spondylitis Disease Activity Score (ASDAS): 2018 update of the nomenclature for disease activity states. Ann Rheum Dis 2018;77:1539-40.

13 Heuft-Dorenbosch L, Spoorenberg A, van Tubergen A, van ver Tempel $\mathrm{H}$, Mielants $\mathrm{H}$, et al. Assessment of enthesitis in ankylosing spondylitis. Ann Rheum Dis 2003;62:127-32.

14 MacKay K, Mack C, Brophy S, et al. The Bath Ankylosing Spondylitis Radiology Index (BASRI): a new, validated approach to disease assessment. Arthritis Rheum 1998;41:2263-70.

15 Twisk JW. Longitudinal data analysis. A comparison between generalized estimating equations and random coefficient analysis Eur J Epidemiol 2004;19:769-76.

16 Wanders A, Landewe R, Dougados M, et al. Association between radiographic damage of the spine and spinal mobility for individual patients with ankylosing spondylitis: can assessment of spinal mobility be a proxy for radiographic evaluation? Ann Rheum Dis 2005;64:988-94.

17 Poddubnyy D, Listing J, Haibel $\mathrm{H}$, et al. Functional relevance of radiographic spinal progression in axial spondyloarthritis: results from the German spondyloarthritis inception cohort. Rheumatol (Oxford, England) 2018;57:703-11.

18 Calvo-Gutierrez J, Garrido-Castro JL, Gil-Cabezas J, et al. Is spinal mobility in patients with spondylitis determined by age, structural damage, and inflammation? Arthritis Care Res (Hoboken) 2015;67:74-9.

19 Ramiro S, van Tubergen A, Stolwijk C, et al. Reference intervals of spinal mobility measures in normal individuals: the mobility study. Ann Rheum Dis 2015;74:1218-24.

20 Tournadre A, Pereira B, Lhoste A, et al. Differences between women and men with recent-onset axial spondyloarthritis: results from a prospective multicenter French cohort. Arthritis Care Res (Hoboken) 2013;65:1482-9.

21 de Carvalho HM, Bortoluzzo AB, Gonçalves CR, et al. Gender characterization in a large series of Brazilian patients with spondyloarthritis. Clin Rheumatol 2012;31:687-95.

22 Landi M, Maldonado-Ficco H, Perez-Alamino R, et al. Gender differences among patients with primary ankylosing spondylitis and spondylitis associated with psoriasis and inflammatory bowel disease in an iberoamerican spondyloarthritis cohort. Medicine 2016;95:e5652.

23 Mogard E, Lindqvist E, Bergman S, et al. Spinal mobility in axial spondyloarthritis: a cross-sectional clinical study. Musculoskeletal Care 2017;15:36-48.

24 Chung HY, Machado P, van der Heijde D, et al. HLA-B27 positive patients differ from HLA-B27 negative patients in clinical presentation and imaging: results from the DESIR cohort of patients with recent onset axial spondyloarthritis. Ann Rheum Dis 2011;70:1930-6.

25 Molto A, Tezenas Du MS, Wendling D, et al. Disease activity trajectories in early axial spondyloarthritis: results from the DESIR cohort. 2017 Jun;76:1036-41.

26 Putrik P, Ramiro S. Lower education and living in countries with lower wealth are associated with higher disease activity in rheumatoid arthritis: results from the multinational COMORA study. 2016 Mar;75:540-6.

27 Cakar E, Taskaynatan MA, Dincer U, et al. Work disability in ankylosing spondylitis: differences among working and work-disabled patients. Clin Rheumatol 2009;28:1309-14.

28 Brophy S, Mackay K, Al-Saidi A, et al. The natural history of ankylosing spondylitis as defined by radiological progression. J Rheumatol 2002;29:1236-43. 